\title{
Effect of Ultraviolet-reflective Mulches on Tomato Yields and on the Silverleaf Whitefly
}

\author{
A.A. Csizinszky, D.J. Schuster, and J.E. Polston \\ University of Florida, Institute of Food and Agricultural Sciences, Gulf Coast \\ Research and Education Center, Bradenton, FL 34203
}

Additional index words. Bemisia argentifolii, Lycopersicon esculentum, tomato mottle virus, soil temperatures, plant height

\begin{abstract}
Field studies were conducted for three seasons, Fall 1994, Spring 1995, and Fall 1995, on the effect of ultraviolet (UV)-reflective films (mulches) on the silverleaf whitefly (Bemisia argentifolii Bellows and Perring), the incidence of tomato mottle virus (ToMoV), and on fruit yields of staked, fresh-market tomatoes (Lycopersicon esculentum Mill.). The UV-reflective mulches were metallized aluminum (aluminum) and painted aluminum (silver) on either black or white plastic film. The aluminum and silver mulches were evaluated with and without a white (fall) or black (spring) 25 -cm-wide painted band in the bed center. Controls were the conventional white (fall) or black (spring) polyethylene mulches. Highest reflected energy $\left(\mu \mathrm{mol} \cdot \mathrm{m}^{-2} \cdot \mathrm{s}^{-1}\right)$ to the plants at $15 \mathrm{~cm}$ from the mulch surface was measured on the aluminum mulch with or without a white painted band. Lowest energy was reflected from the white or black controls and from silver on black mulches with or without a black painted band. Whitefly populations in the fall were lower $(P \leq 0.05)$ on the aluminum than on the silver mulches. In the spring, when whitefly populations were low, whiteflies were more numerous on the black control and silver on white, than on the aluminum mulches. In the fall seasons, the proportion of plants with symptoms of ToMoV transmitted by the silverleaf whitefly were higher on the controls than on the aluminum mulch. In the spring, the proportion of plants with symptoms was not affected by mulch treatments. Yields in the fall were similar with UV-reflective or white control mulches. In the spring, fruit size and marketable yields were greater $(P \leq$ 0.05) on plants with silver on white mulch than on the control black mulch.
\end{abstract}

Tomato mottle virus (ToMoV), transmitted by the silverleaf whitefly, became a serious problem for Florida tomato growers in the late 1980s and resulted in greatly reduced yields contributing to economic losses (Polston et al., 1993). The availability of a systemic insecticide, imidacloprid $\{1-[(6-$ chloro-3-pyridinyl $)$ methyl]- $N$-nitro-2-imidazolidinimide $\}$ reduced whitefly populations and the incidence of ToMoV infection in tomatoes. However, the whitefly has developed tolerance to the insecticide in Spain (Cahill et al., 1996). Consequently, alternative methods to protect vegetable crops from these insects are needed. In previous studies, vegetable crops raised on beds covered with aluminum-painted mulch had a reduced incidence of insect-transmitted virus infection, in comparison with crops raised on black or white polyethylene mulch, or on bare soil. For example, damage from mosaic virus transmitted by aphids (Aphididae) was reduced in watermelon and in squash (Adlerz and Everett, 1968; Lamont et al., 1990); the

Received for publication 10 Oct. 1997. Accepted for publication 15 Sept. 1998. We thank Vacumet Corp., Wayne, N.J., and Polygro Plastics, Agandilla, Puerto Rico, for supplying the plastic films for this project. Florida Agricultural Experiment Station journal Series No. R-05998. The cost of publishing this paper was defrayed in part by the payment of page charges. Under postal regulations, this paper therefore must be hereby marked advertisement solely to indicate this fact. incidence of tomato spotted wilt virus transmitted by thrips (Thripidae) was reduced $64 \%$ in tomato (Greenough et al., 1990); and development of symptoms of ToMoV, transmitted by whitefly, was delayed on tomato (Csizinszky et al., 1995, 1997). The reason for the reduced incidence of virus damage to the crops was that aluminum-painted mulch reflects light in the B (400-500 $\mathrm{nm})$ and in the near-ultraviolet $(395 \mathrm{~nm})$ regions of the spectrum. The light reflected in these regions repels the insects before they visit the plants (Ham et al., 1991; Kring, 1972). The aluminum surface mulch also emits less long-wave radiation to the leaf surface, resulting in 2 to $3{ }^{\circ} \mathrm{C}$ lower leaf temperatures than on black or on white mulch (Ham et al., 1991). Soil temperatures at the 10$\mathrm{cm}$ depth were also 3 to $5^{\circ} \mathrm{C}$ lower in aluminum-mulched beds than in black-mulched ones (Csizinszky et al., 1995; Ham et al., 1991). The lower leaf and root-zone temperatures on the aluminum mulch increased plant height and yields. However, Schalk and Robbins (1987) reported that aluminum mulch increased fruit injury by the tomato pinworm [Keiferia lycopersicella (Walsingham)] and the tomato fruitworm [Helicoverpa zea (Boddie)] compared with the control.

The objectives of this study were to evaluate plant growth, yields, whitefly populations, and the incidence of ToMoV on staked, freshmarket tomatoes grown on various commercially produced aluminum mulches.
Studies were conducted in Fall 1994 and Spring and Fall 1995 on Eau Gallie fine sand (sandy silicaceous hyperthermic Alfic Haplaquod). Treatments were arranged in each study as a randomized complete-block design with four replications. Each treatment (mulch type) consisted of three adjacent mulched beds per block, each $6.4 \mathrm{~m}$ long, $81 \mathrm{~cm}$ wide, and 20 $\mathrm{cm}$ high, formed on 1.5 -m centers. There were seven mulches evaluated in the experiments: 1) black or white on black 38-m-thick polyethylene (Integro, Tampa, Fla.), which were standards for the spring and fall, respectively; 2) metallized, "foil-like" aluminum (termed aluminum) on white plastic (Vacumet Corp., Wayne, N.J.); 3) metallized aluminum on white plastic with a 23 -cm-wide nonmetallized white or hand-painted black strip down the middle (termed aluminum + strip); 4) aluminum, "painted-like" matrix on black plastic (termed silver on black) (Polygro Plastics, Agandilla, Puerto Rico); 5) aluminum matrix on black plastic with a $23-\mathrm{cm}$-wide white or black handpainted strip down the middle (termed silver on black + strip); 6) aluminum matrix on white plastic (termed silver on white); and 7) aluminum matrix on white plastic with a white or black hand-painted strip down the middle (termed silver on white + strip). Mulches with a white strip were used in fall experiments and mulches with a black strip were used in spring experiments. Strips, except for the white strip on aluminum mulch (in treatment no. 3 ), were made with white or black latex exterior paint (Lucite House and Trim) diluted 1:1 (v/v) with water and applied with a hand-held $\mathrm{CO}_{2}$-powered sprayer with an adjustable cone nozzle.

Before laying the mulch, each treatment received the equivalent, in $\mathrm{kg} \cdot \mathrm{ha}^{-1}$, of $293 \mathrm{~N}$, $38 \mathrm{P}, 486 \mathrm{~K}, 0.59 \mathrm{~B}, 0.59 \mathrm{Cu}, 3.51 \mathrm{Fe}, 1.46 \mathrm{Mn}$, $0.04 \mathrm{Mo}$, and $1.37 \mathrm{Zn}$. The soil was fumigated with Terr-0-Gas (66.6\% methylbromide and $33.3 \%$ chloropicrin) at $239 \mathrm{~kg} \cdot \mathrm{ha}^{-1}$. Two weeks after fumigation, on 15 Aug. 1994, 5-weekold 'Florisette' and on 3 Mar. and 13 Sept. 1995, 5-week-old 'Sunbeam' tomato seedlings were transplanted in a single row per bed at 46-cm spacing. Plants were staked, then tied three times during the season. Irrigation was applied by the seepage (modified furrow) system. Plant pathogens were controlled by weekly applications of labeled fungicides and bactericides. Lepidopterous larvae were controlled by weekly applications of Bacillus thuringiensis (Berliner) and methomyl as needed.

Reflected radiation from the mulch surface to the adaxial side of leaves was measured with a radiometer (LI-185A; LI-COR Instrument Co., Lincoln, Nebr.) with a quantum sensor (Lambda Instrument Corp., Lincoln, Nebr.) held $15 \mathrm{~cm}$ above the top of the bed. Measurements were made periodically during the season between 1300 and $1400 \mathrm{HR}$ at four locations per plant (north, south, east, and west) on six plants per treatment until the expanding foliage covered the mulch. Soil temperatures at $10 \mathrm{~cm}$ deep were measured by AU-metal dial thermometers (Fisher Scien- 
tific, Pittsburgh) in each plot on weekdays during the season between 1400 and $1530 \mathrm{HR}$. Plant heights on six adjacent plants in the middle of each plot were measured periodically. Silverleaf whitefly evaluations were made on the middle 10 plants from the middle row in each plot. The number of whitefly adults were counted weekly on the terminal leaflet of one leaf of each plant. Leaves were carefully inverted and adults counted in the morning hours when adults are less easily disturbed. Crawlers, sessile nymphs, and puleaflet of the seventh leaf from the top of each of the 10 plants. Plants in each plot were inspected weekly for apparent virus symptoms and tagged when symptoms were visible.

Fruit were harvested from 10 consecutive plants in the center rows at the breaker or more mature stage four times at weekly intervals in Fall 1994 and three times in Spring and Fall 1995. Fruit were separated into marketable and cull; then marketable fruit were size-graded by machine as extra-large ( $\geq 70 \mathrm{~mm}$ diameter), large $(63.5-70.6 \mathrm{~mm})$, and medium (57.2$64.3 \mathrm{~mm}$ ). The number and weight of fruit in each grade were recorded.

Data were analyzed by analysis of variance (ANOVA) (SAS Institute, 1988). When significant F-values were found, differences between means were determined by calculating the least significant difference (LSD) or by using Duncan's multiple range test.

\section{Results}

Photosynthetically active radiation (PAR) values. The energy of $P A R\left(\mu \mathrm{mol} \cdot \mathrm{m}^{-2} \cdot \mathrm{s}^{-1}\right)$ reflected from the mulches onto the plants was pae were counted biweekly on the terminal

highest on the aluminum, silver on white + strip, and silver on black + strip treatments in Aug. 1994 and similarly high from the aluminum + strip in Sept. 1994. In Spring and Fall 1995, the reflected energy was highest from the aluminum and from the aluminum + strip treatments (Table 1).

Soil temperatures. Soil temperatures in Fall 1994 were highest under the aluminum + strip mulch, reaching $33^{\circ} \mathrm{C}$ on 25 Aug. (Table 2 ), whereas soil temperatures under the silver on white + strip mulch were 5.6 to $6.5^{\circ} \mathrm{C}$ lower than under the aluminum + strip mulch. In Spring 1995, soil temperatures were 5 to $6{ }^{\circ} \mathrm{C}$ higher early in the season on 22 Mar. than in May because of lower than average daily temperatures in late April and early May in westcentral Florida. Under these conditions, soil temperatures on $22 \mathrm{Mar}$. ranged from $26.7^{\circ} \mathrm{C}$ under the aluminum mulch to $31.8{ }^{\circ} \mathrm{C}$ under the black control treatment, but on 3 May the difference between the lowest $\left(24.4^{\circ} \mathrm{C}\right.$ under the silver on white) and highest soil temperature $\left(25.3^{\circ} \mathrm{C}\right.$ under the silver on black + strip and silver on white + strip) was less $\left(0.9^{\circ} \mathrm{C}\right)$. In Fall 1995, early in the season (20 Sept.), soil temperature was highest $\left(35.0^{\circ} \mathrm{C}\right)$ under the silver on black mulch but soil temperatures under the control (white), silver on white, and aluminum + strip mulches were statistically similar. Soil temperature differences among mulch treatments during the season were less variable than in the earlier studies and varied only 2 to $3{ }^{\circ} \mathrm{C}$.

Plant height. Mulch treatments had little effect on plant heights in either season (data not presented).

Yield. Early (first harvest) yields of extralarge ( $\geq 70 \mathrm{~mm}$ diameter) fruit of the 'Florisette'

Table 1. Quanta of photosynthetically active radiation reflected from mulches at $15 \mathrm{~cm}$ from surface.

\begin{tabular}{|c|c|c|c|c|c|c|}
\hline \multirow[b]{3}{*}{ Mulch } & \multicolumn{6}{|c|}{ Season and date } \\
\hline & \multicolumn{2}{|c|}{ Fall 1994} & \multicolumn{2}{|c|}{ Spring 1995} & \multicolumn{2}{|c|}{ Fall 1995} \\
\hline & 17 Aug. & 22 Sept. & 15 Mar. & $19 \mathrm{Apr}$. & 20 Sept. & 20 Oct. \\
\hline & \multicolumn{6}{|c|}{$\mu \mathrm{mol} \cdot \mathrm{m}^{-2} \cdot \mathrm{s}^{-1 \mathrm{z}}$} \\
\hline Control $^{y}$ & $672 c^{x}$ & $367 \mathrm{~d}$ & $35 \mathrm{c}$ & $84 \mathrm{~d}$ & $618 \mathrm{~d}$ & $378 \mathrm{~cd}$ \\
\hline Aluminum & $1134 \mathrm{a}$ & $814 \mathrm{a}$ & $169 \mathrm{~b}$ & $1083 \mathrm{a}$ & $1144 \mathrm{a}$ & $599 \mathrm{ab}$ \\
\hline Aluminum + strip & $643 c$ & $722 a b$ & 318 a & $1000 \mathrm{a}$ & $699 \mathrm{~cd}$ & $744 \mathrm{a}$ \\
\hline Silver on black & $739 \mathrm{bc}$ & $524 \mathrm{~cd}$ & $178 \mathrm{~b}$ & $342 \mathrm{c}$ & $594 \mathrm{~d}$ & $251 \mathrm{~d}$ \\
\hline Silver on black + strip & 1021 a & $474 d$ & $57 \mathrm{c}$ & $253 \mathrm{c}$ & 948 b & $275 \mathrm{~cd}$ \\
\hline Silver on white & $809 \mathrm{~b}$ & $545 \mathrm{~b}-\mathrm{d}$ & $213 \mathrm{~b}$ & $640 \mathrm{~b}$ & $746 c$ & $480 \mathrm{bc}$ \\
\hline Silver on white + strip & $1060 \mathrm{a}$ & $676 a-c$ & $64 c$ & $517 \mathrm{~b}$ & $976 \mathrm{~b}$ & $441 \mathrm{~b}-\mathrm{d}$ \\
\hline
\end{tabular}

${ }^{2}$ Averaged over four locations per plant, six plants per mulch treatment and four replications.

${ }^{y}$ Control: black mulch in spring and white on black in fall; for the description of other mulches, see text. ${ }^{x}$ Mean separation within columns by Duncan's multiple range test at $P \leq 0.05$. tomato in Fall 1994 ranged from $0.1 \mathrm{t} \cdot \mathrm{ha}^{-1}$ with the silver on white mulch to $0.9 \mathrm{t} \cdot \mathrm{ha}^{-1}$ with the control (white mulch) and the silver on white + strip treatments (Table 3 ). Marketable yields in the first harvest ranged from $2.2 \mathrm{t} \cdot \mathrm{ha}^{-1}$ with the silver on black + strip and silver on white treatments to $4.8 \mathrm{t} \cdot \mathrm{ha}^{-1}$ with the silver on white $+\operatorname{strip}$ mulch $(P \leq 0.05)$. For the season, yields of extra-large fruit yields were lower $(P \leq$ $0.05)$ with the silver on white + strip mulch than with the other treatments. except for silver on white mulch. Highest yield of extralarge fruit was obtained with the aluminum mulch. Marketable yields for the season were higher $(P \leq 0.05)$ with the aluminum and with the silver on black mulches than with silver on white + strip, silver on black +strip, and silver on white mulches. In Spring 1995, early yields of extra-large and marketable fruit of 'Sunbeam' tomato were higher $(P \leq 0.05)$ with silver on white than with any other treatment except silver on black strip (Table 3). For the season, both extra-large and marketable total yields were higher $(P \leq 0.05)$ with silver on white mulch than with the black control, silver on black, silver on white + strip, and with the aluminum mulches. In Fall 1995, early and season's total yields of extra-large and marketable fruit were similar with all six mulch treatments (Table 3).

Whitefly population. Average numbers of adult whiteflies and their first appearance on the plants varied among the seasons and among the mulch types within seasons (Table 4). In Spring 1995, whiteflies were first detected on the plants at $49 \mathrm{~d}$ after planting (DAP) and their numbers remained low until 77 DAP. In both fall seasons, whiteflies were present on the plants at and after 21 DAP. There was little or no consistency between the number of whiteflies on the plants and mulch types within seasons. However, in Fall 1994, in several cases higher numbers of whiteflies were counted on plants with the silver on white + strip treatment, than on plants in many of the other treatments (Table 4).

Virus symptoms. The cumulative percentage of plants with apparent virus symptoms also varied among seasons (Table 4). In Spring 1995 , only a few plants had virus symptoms during the first 77 DAP. At the end of the season (9 June, 98 DAP), the proportion of plants with virus symptoms ranged from $18 \%$ with the silver on white to $31 \%$ with the black control mulch. In both fall seasons, the proportion of virus-infected plants increased rapidly

Table 2. Soil temperatures $\left({ }^{\circ} \mathrm{C}\right)$ at $10-\mathrm{cm}$ depth in plant beds covered with UV-reflective mulches.

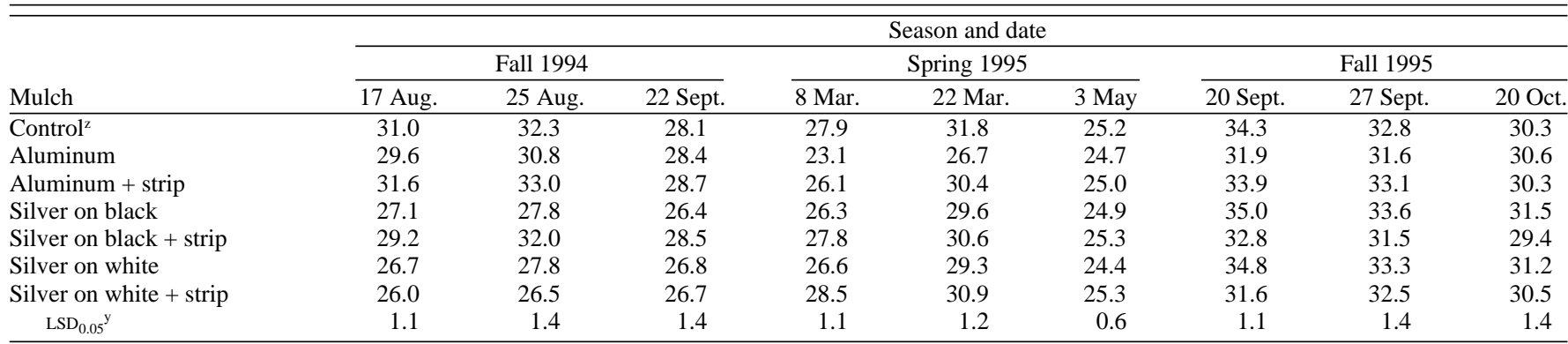

${ }^{2}$ Control: black mulch in spring and white on black in fall; for the description of other mulches, see text.

${ }^{y}$ LSD values for paired comparisons within each column. 
Table 3. Early and seasonal total yields of tomatoes on UV-reflective mulches.

\begin{tabular}{|c|c|c|c|c|}
\hline \multirow[b]{2}{*}{ Treatment } & \multicolumn{2}{|c|}{$\begin{array}{r}\text { Early } \\
\end{array}$} & \multicolumn{2}{|c|}{ Season's total $\left(\mathrm{t} \cdot \mathrm{ha}^{-1}\right)$} \\
\hline & Extra-large $^{z}$ & $\overline{\text { Marketable }}$ & Extra-large $^{z}$ & Marketable \\
\hline & \multicolumn{4}{|c|}{ Fall 1994, cv. Floriset } \\
\hline Control $^{\mathrm{y}}$ & 0.9 & 3.6 & 7.6 & 26.4 \\
\hline Aluminum & 0.2 & 3.1 & 9.3 & 33.7 \\
\hline Aluminum + strip & 0.8 & 4.1 & 8.5 & 27.7 \\
\hline Silver on black & 0.4 & 2.5 & 7.8 & 33.0 \\
\hline Silver on black + strip & 0.5 & 2.2 & 8.0 & 22.5 \\
\hline Silver on white & 0.1 & 2.2 & 6.5 & 23.2 \\
\hline Silver on white + strip & 0.9 & 4.8 & 4.1 & 19.8 \\
\hline \multirow[t]{2}{*}{$\operatorname{LSD}_{0.05}{ }^{x}$} & 0.7 & 1.8 & 2.6 & 9.2 \\
\hline & \multicolumn{4}{|c|}{ Spring 1995, cv. Sunbeam } \\
\hline Control $^{\mathrm{y}} 23.9$ & 25.6 & 48.7 & 65.8 & \\
\hline Aluminum & 27.1 & 29.0 & 53.7 & 71.1 \\
\hline Aluminum + strip & 26.7 & 28.7 & 56.9 & 73.5 \\
\hline Silver on black & 27.2 & 29.2 & 50.7 & 67.0 \\
\hline Silver on black + strip & 30.4 & 32.0 & 58.6 & 73.6 \\
\hline Silver on white & 34.2 & 36.4 & 64.5 & 82.6 \\
\hline Silver on white + strip & 26.6 & 29.0 & 52.1 & 69.6 \\
\hline \multirow[t]{2}{*}{$\operatorname{LSD}_{0.05}{ }^{x}$} & 4.7 & 5.0 & 9.3 & 9.8 \\
\hline & \multicolumn{4}{|c|}{ Fall 1995, cv. Sunbeam } \\
\hline Control $^{\text {y }} 4.8$ & 6.4 & 13.5 & 32.7 & \\
\hline Aluminum & 6.1 & 8.5 & 14.5 & 37.5 \\
\hline Aluminum + strip & 3.5 & 6.4 & 10.1 & 32.3 \\
\hline Silver on black & 6.1 & 8.1 & 14.1 & 33.7 \\
\hline Silver on black + strip & 5.4 & 7.3 & 12.4 & 30.7 \\
\hline Silver on white & 4.9 & 6.9 & 14.2 & 33.3 \\
\hline Silver on white + strip & 4.4 & 6.4 & 12.0 & 32.6 \\
\hline $\operatorname{LSD}_{0.05}{ }^{\mathrm{x}}$ & NS & NS & NS & NS \\
\hline
\end{tabular}

${ }^{\mathrm{z}}>70 \mathrm{~mm}$ diameter.

${ }^{\mathrm{y}}$ Control: black mulch in spring and white on black in fall. For the description of other treatments, see text. ${ }^{\mathrm{x}} \mathrm{LSD}$ is nonsignificant (NS) or significant at $P \leq 0.05$. as the season progressed and from $89 \%$ to $100 \%$ of the plants had virus symptoms at 98 DAP, regardless of the mulch treatment (Table 4). In Fall 1994, plants on the aluminum + strip mulch had a lower proportion $(P \leq 0.05)$ of plants with virus symptoms at all four sampling dates than plants with the white control mulch. In the Fall 1995 study, the aluminum mulch from 63 to 98 DAP reduced the proportion of plants with virus symptoms.

\section{Discussion}

In this study, yield differences between the fall and spring crops and yield differences between mulch treatments within seasons can probably be attributed to the time of appearance and the proportion of plants with virus symptoms. In the fall, whiteflies were present at the time of the planting and many plants had virus symptoms early in the season. In the spring, whitefly populations increase slowly with increasing temperatures and infect plants late in the season near the first harvest. In our study at 77 DAP in Spring 1995, only 0 to 3\% of the plants had virus symptoms, while $50 \%$ to $73 \%$ and $76 \%$ to $97 \%$ of the plants were infected with the virus in Fall 1994 and Fall 1995, respectively. Consequently, the ToMoV was less detrimental to fruit yields in the spring than in the fall.

Yields with the silver on white mulch in Spring 1995 were higher $(P \leq 0.05)$ than those with the black control. The reason(s) for this are not clear, but may be due to the lack of symptoms of virus infection during most of the season. Even at the end of harvest (98

Table 4. Average number of adult whiteflies per terminal tomato leaflet and cumulative percentage of plants with apparent virus symptoms on selected days after planting (DAP).

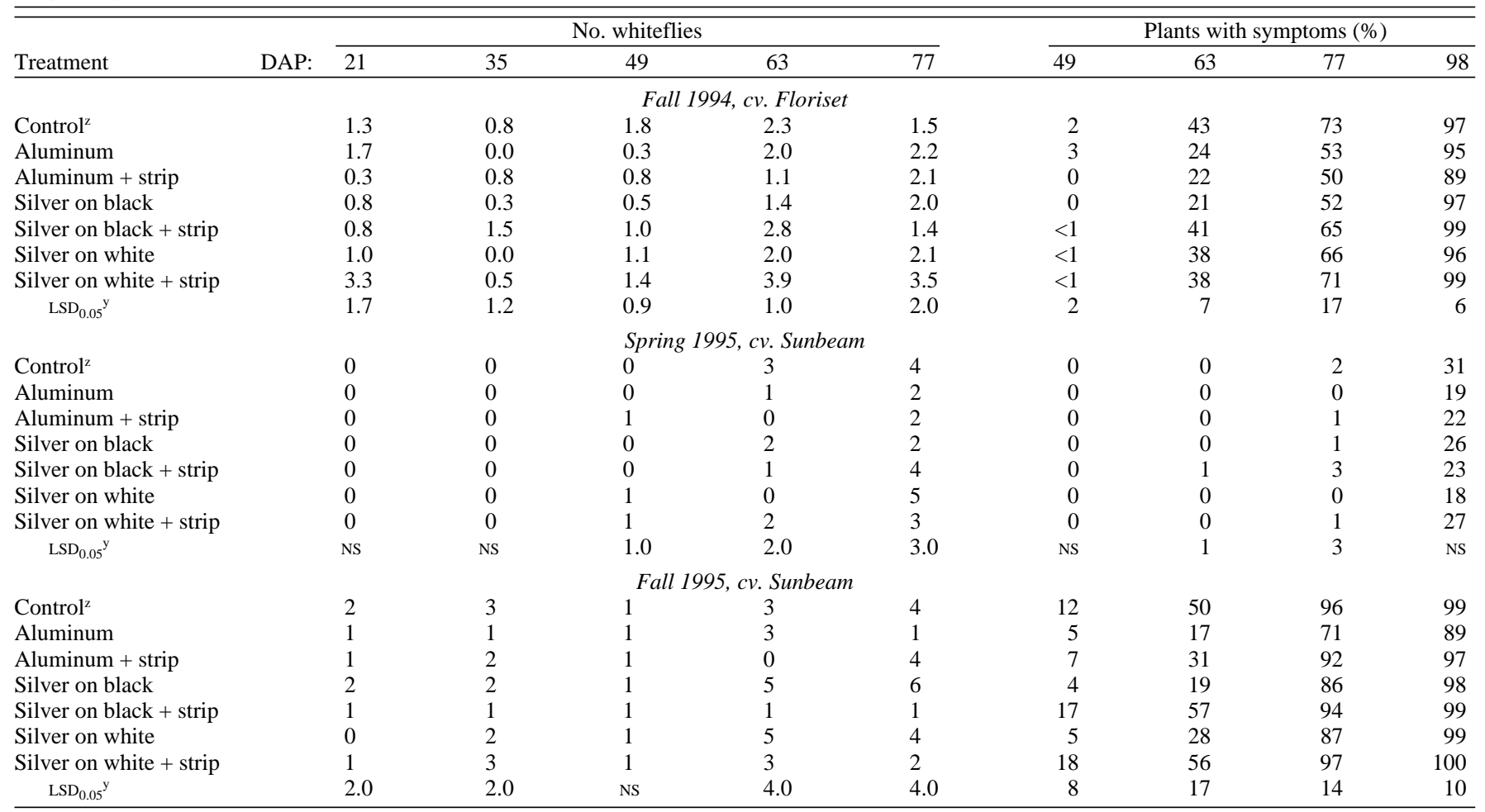

${ }^{2}$ Control: white on black mulch in fall and black mulch in spring; for the description of other treatments, see text.

${ }^{{ }^{\mathrm{LSD}}}$ is nonsignificant (NS) or significant at $P \leq 0.05$. 
DAP), only $18 \%$ of the plants on the silver on white mulch had apparent virus symptoms vs. $31 \%$ of those on the black mulch. There was also a trend, although nonsignificant, toward higher cumulative yields with the aluminum than with the white or black control mulch. In our previous studies (Csizinszky et al., 1995, 1997), tomato fruit size and marketable yields were also higher with the aluminum than with the conventional white mulch. The increased yields were attributed to fewer whiteflies on the plants and to a lower proportion of virusinfected plants, especially during the first 2 months after planting, than with the white mulch. The insect-repellent characteristics of the aluminum mulch, as reported earlier by other researchers (Greenough et al., 1990; Schalk and Robbins, 1987; Wolfenbarger and Moore, 1968) could be used in combination with insecticides to reduce insect damage. Early in the season, when plants are small, the UV-reflectant characteristics of the aluminum or silver mulch repel the insects; thus, the number of insecticidal spray applications may be reduced. Later in the season, when the expanding plants cover the surface, timely applications of insecticidal sprays could control insects that transmit virus diseases.

In spite of the trend toward higher yields with the aluminum than with the control mulches, growers have to consider the high cost of the aluminum mulch, thus the high preharvest investment. The price of one roll (732 $\mathrm{m}$ or $2400 \mathrm{ft}$ ) of aluminum mulch is $\$ 185.00$, whereas the black mulch costs $\$ 60.80$, white on black $\$ 88.30$, and silver on black or silver on white $\$ 89.10$. The cost of the higherpriced mulch must be weighed against the expected benefits from higher yields and good market price for the fruit by the grower when selecting the best mulch for tomatoes.

Further studies should be conducted on the best type of mulch for the spring and fall seasons, on the combination of mulch types and the feasibility of reduced pesticide applications, and on the economic analyses of mulch types and pesticide applications.

\section{Literature Cited}

Adlerz, W.C. and P.H. Everett. 1968. Aluminum foil and white polyethylene mulches to repel aphids and control watermelon mosaic. J. Econ. Entomol. 61:1276-1279.

Cahill, M., K. Gorman, S. Day, I. Denholm, A. Elbert, and R. Na. 1996. Baseline determination and detection of resistance to imidacloprid in Bemisia tabaci (Homoptera: Aleyrodidae). Bul. Entomol. Res. 86:843-849.

Csizinszky, A.A., D.J. Schuster, and J.B. Kring. 1995. Color mulches influence yield and insect pest populations in tomatoes. J. Amer. Soc. Hort. Sci. 120:778-784.
Csizinszky, A.A., D.J. Schuster, and J.B. Kring. 1997. Evaluation of color mulches and oil sprays for yield and for the control of silverleaf whitefly, Bemisia argentifolii (Bellows and Perring), on tomatoes. Crop Protection 16:475-481.

Greenough, D.R., L.L. Black, and W.P. Bond. 1990. Aluminum-surfaced mulch: An approach to the control of tomato spotted wilt virus in solanaceous crops. Plant Dis. 74:805-808.

Ham, J.M., G.J. Kluitenberg, and W.J. Lamont. 1991. Potential impact of plastic mulches on the aboveground plant environment, p. 63-69. Proc. Natl. Agr. Plastics Congr., Mobile, Ala., 29 Sept.-3 Oct. 1991.

Kring, J.B. 1972. Flight behavior of aphids. Annu. Rev. Entomol. 17:461-492.

Lamont, W.J., K.A. Sorensen, and C.W. Averre. 1990. Painting aluminum strips on black plastic mulch reduces mosaic symptoms on summer squash. HortScience 25:1305.

Polston, J.E., E. Hiebert, R.J. McGovern, P.A. Stansly, and D.J. Schuster. 1993. Host range of tomato mottle virus, a new geminivirus infecting tomato in Florida. Plant Dis. 77:1181-1184.

SAS Institute. 1988. SAS/STAT user's guide. Release 6.03 ed. SAS Inst., Cary, N.C.

Schalk, J.M. and M. Le Ron Robbins. 1987. Reflective mulches influence plant survival, production, and insect control in fall tomatoes. HortScience 22:30-32.

Wolfenbarger, D.O. and W.D. Moore. 1968. Insect abundances on tomatoes and squash mulched with aluminum and plastic sheetings. J. Econ. Entomol. 61:34-36. 